\title{
REVIEW OF MEDICINAL USES, PHYTOCHEMISTRY, AND PHARMACOLOGICAL PROPERTIES OF DRIMIA ELATA
}

\author{
ALFRED MAROYI* \\ Department of Botany, Medicinal Plants and Economic Development Research Centre, University of Fort Hare, Private Bag X1314, Alice, \\ South Africa. Phone: 0027719600326. Email: amaroyi@ufh.ac.za
}

Received: 18 December 2018, Revised and Accepted: 11 February 2019

\begin{abstract}
Drimia elata is an important and well-known medicinal plant in tropical Africa. This study critically reviewed the medicinal applications, phytochemistry, and pharmacological activities of D. elata. Literature on medicinal applications, phytochemical, and pharmacological activities of D. elata was collected from multiple internet sources including Elsevier, Google Scholar, SciFinder, Web of Science, PubMed, BMC, ScienceDirect, and Scopus. Complementary information was gathered from pre-electronic sources such as books, book chapters, theses, scientific reports, and journal articles obtained from the university library. This study showed that D. elata is used for treating several medical conditions, particularly general ailments, blood and cardiovascular system, reproductive system and sexual health, urinary system, infections and infestations, digestive system, respiratory system, and muscular-skeletal system disorders. Phytochemical compounds identified from the species include bufadienolides, alkaloids, aromatic acids, flavonoids, phlobatannins, saponins, steroids, tannins, and terpenoids. Ethnopharmacological research revealed that D. elata extracts have acetylcholinesterase enzyme inhibitory, antibacterial, antifungal, antimycobaceterial, anticancer, anti-inflammatory, antioxidant, hemagglutinating, and cytotoxicity activities. D. elata should be subjected to extensive in vivo experiments and also future studies should focus on how potential toxic components of the species can be managed when it is used as herbal medicine.
\end{abstract}

Keywords: Asparagaceae, Drimia elata, Herbal medicine, Tropical africa.

(C) 2019 The Authors. Published by Innovare Academic Sciences Pvt Ltd. This is an open access article under the CC BY license (http://creativecommons. org/licenses/by/4. 0/) DOI: http://dx.doi.org/10.22159/ajpcr.2019.v12i4.30963

\section{INTRODUCTION}

Drimia elata Jacq. is an important and well-known medicinal plant in South Africa. Van et al.[1] provide an excellent introduction to the ethnopharmacological properties of D. elata and several other important medicinal plants in South Africa. D. elata is an ingredient of at least two traditional herbal concoctions in South Africa, known as "imbizae phuzwato" and "intelezi" that are sold commercially in the country. A herbal tonic, imbizae phuzwato is made from a mixture of roots, bulbs, rhizomes, and leaves of Acokanthera oppositifolia (Lam.) Codd, Aster bakeranus Burtt Davy ex C.A. Sim., Corchorus asplenifolius Burch., Cyrtanthus obliquus (L.f.) Aiton, Fusifilum physodes (Jacq.) Raf. ex Speta, Eriosema cordatum E.Mey., Gnidia kraussiana Meisn. var. kraussiana, Gomphocarpus fruticosus (L.) W.T. Aiton, Gunnera perpensa L., Hypericum aethiopicum Thunb., Ledebouria spp., Lycopodium clavatum L., Momordica balsamina L., Rubia cordifolia L., Scadoxus puniceus (L.) Friis and Nordal, Stephania abyssinica (Quart.-Dill. and A. Rich.) Walp., Tetradenia riparia (Hochst.) Codd, Vitellariopsis marginata (N.E.Br.) Aubrév, Watsonia densiflora Bak., and Zanthoxylum capense (Thunb.) Harv. [2,3]. The concoction is used as an energizing and detoxifying tonic used against general body pains, stress, constipation, arthritis, kidney problems, high blood pressure, and to increase sexual prowess [2,3]. D. elata is also an ingredient of "intelezi," whose plant species composition varies from region to region of South Africa. Intelezi is used to protect households from evil spirits and lightning, and also to chase away, ward off or root out evil spirits [4]

D. elata is the third most popular bulbous medicinal plant used in South African traditional therapy [5] and is one of the topmost wild-harvested species sold in the informal economy trade in the Eastern Cape [6,7], Gauteng [8-10], KwaZulu-Natal [8,11], Limpopo [12], and the Western Cape $[7,13,14]$ provinces in South Africa. Research by Ndawonde et al. [15] showed that D. elata bulb was sold by $>50.0 \%$ of the traders in KwaZulu-Natal Province, while Philander et al. [14] revealed that bulbs of the species were sold by $35 \%$ of the traders in the Western
Cape province, with $60.48 \mathrm{~kg}$ of the bulb fetching US\$26.21. Earlier research by Dold and Cocks [6] revealed that D. elata is among the most frequently traded species in the Eastern Cape Province with $113.9 \mathrm{~kg}$ as the mean quantity traded per trader per annun with a kilogram of the bulb fetching US\$3.36. Marshall [16] argued that D. elata is scarce and heavily traded in South Africa, characterized by a high monetary value in the country. Due to increasing demand for the species, D. elata is managed in herbal medicine home gardens in the Eastern Cape [17], Limpopo [18-20], and the Western Cape [14] provinces. Research by Wiersum et al. [17] revealed that D. elata is among the ten most frequently cultivated herbal medicines in medicinal home gardens in the Eastern Cape Province. It is, therefore, within this context that the current study was undertaken aimed at summarizing the medicinal uses, phytochemical, and ethnopharmacological properties of D. elata so as to evaluate its therapeutic importance throughout its distributional range.

\section{BOTANICAL PROFILE AND DESCRIPTION OF D. ELATA}

The genus Drimia Jacq. is a large group of deciduous geophytes belonging to the family Asparagaceae, previously included in the Hyacinthaceae family. The family of Hyacinthaceae is divided into four monophyletic subfamilies, namely Hyacinthoideae, Ornithogaloideae, Oziroeoideae, and Urginoideae [21]. At present, this family is considered as a subfamily Scilloideae in the expanded Asparagaceae sensu [22,23]. The species in each subfamily synthesize specialized secondary metabolites with Hyacinthoideae synthesizing homoisoflavanones and triterpenoids, Ornithogaloideae (cardenolides and steroidal glycosides), and Urgineoideae synthesizing bufadienolides [21]. The subfamily Urgineoideae has flat or winged seeds characterized by brittle, loosely adhering test a comprising genera Bowiea Harv. ex Hook. f. and Drimia [24].The genus Drimia is described by Manning et al. [24,25] in an inclusive and broad sense, including genera such as Litanthus Harv., Mucinea M. Pinter et al., Rhadamanthus Salisb., Rhodocodon Baker, Sagittanthera Mart-Azorín et al., Thuranthos C. H. Wright, Tenicroa Raf., and Urginea Steinh. The taxonomy of genus Drimia has always 
been difficult with several species treated under genus Urginea until Jessop [26] reduced Urginea to a synonym of Drimia. The genus consists of about 100 bulbous species distributed in Southern Africa through tropical Africa to the Mediterranean, Asia, and Madagascar [24]. Synonyms of $D$. elata include D. alta R.A. Dyer, D. ciliaris Jacq. ex Willd., D. purpurascens J. Jacq., D. robusta Baker, D. villosa (Lindl.) Kunth, D. zombensis Baker, Idotheaelata Kunth, I. ciliaris (Jacq. ex Willd.) Kunth, I. purpurascens (J. Jacq.) Kunth, I. robusta (Baker) Kuntze, and I. villosa (Lindl.) Kunth [1,27-31].

D. elata is a geophyte with large underground bulb, strap-shaped leaves and long, slender flowering stalk which grows up $1.8 \mathrm{~m}$ in height $[1,27-29,31]$. The flowers are tubular, whitish to purple in color with the tips of the petals characteristically reflexed and the stamens fused into a narrow tube [1]. D. elata has been recorded in grassland, often among rocks at an altitude ranging from $15 \mathrm{~m}$ to $1650 \mathrm{~m}$ above sea level [29]. The species has been recorded in Botswana, Angola, Malawi, Kenya, South Africa, Swaziland, Zambia, South Sudan, Tanzania, Sudan, Uganda, Zimbabwe, and Mozambique [1,27-31](Fig. 1).

\section{MEDICINAL USES OF D. ELATA}

The medicinal applications recorded from literature were classified into ten medical categories following the Economic Botany Data Collection Standard [32] with some changes proposed by Macía et al. [33] and Gruca et al. [34]. This review showed that D. elata is used for treating several medicinal conditions, particularly general ailments, blood and cardiovascular system, reproductive system and sexual health, urinary system, infections and infestations, digestive system, respiratory system, and muscular-skeletal system disorders (Fig. 2). D. elata is used as herbal medicine against three out of five diseases categorized by the World Health Organization (WHO) as the top five killer diseases in sub-Saharan Africa in 2012. These diseases include human immunodeficiency virus/acquired immune deficiency syndrome (HIV/AIDS), lower respiratory tract infections, and diarrheal diseases [35]. Most medicinal uses are linked to the bulb and leaf or the entire plant in ritual or magical uses, and the species is also used mixed with other plant species (Table 1). Research by Gurib-Fakim [36] and Maroyi $[37,38]$ revealed that traditional medicines are often prepared by combining several different plant species to effect synergistic properties or to initiate an interaction with a relevant molecular target.

\section{PHYTOCHEMICAL CONSTITUENTS OF D. ELATA}

D. elata is characterized by cardiac glycosides, particularly bufadienolides. All the bufadienolides that have been isolated from D. elata are collated in Table 2. Kellerman et al. [59,60] argued that bufadienolide containing plants are toxic to livestock with an estimated 33\% of plant-related mortality in cattle in South Africa attributed to this compound. Van et al. [61] argued that there is a danger of accidental poisoning or that people may be harmed if bulbs of D. elata are used indiscriminately as rubbing the bulb scales or leaves on bare skin produces a stinging and irritating effect and a skin rash is produced. However, bufadienolides are known to have a wide range of biological activities including anti-tumor, antiproliferative, and cytotoxic activities [62-68].

Koorbanally et al. [69] identified aromatic acids, 4-hydroxy-3methoxybenzoic acid, 3,4-dihydroxybenzoic acid, and trans-3-(4'hydroxyphenyl)-2-propenoic acid from the ethyl acetate bulb extract of D. elata. Matotoka and Masoko [70] identified flavonoids, phlobatannins, saponins, tannins, and terpenoids from the D. elata bulb (Table 3). Similarly, Matotoka and Masoko [41] identified alkaloids, flavonoids, saponins, steroids, tannins, and terpenoids from a herbal mixture of D. elata bulb mixed with leaves of Monsonia angustifolia, Sarcostemma viminale and Vahlia capensis, Kirkia wilmsii (leaves, roots, and twigs), and Hypoxis hemerocallidea (corm).

Okem et al. [71] argued that D. elata bulbs obtained from the herbal medicine informal markets in Pietermaritzburg, KwaZulu-Natal Province in South Africa contained high levels of heavy metals, with

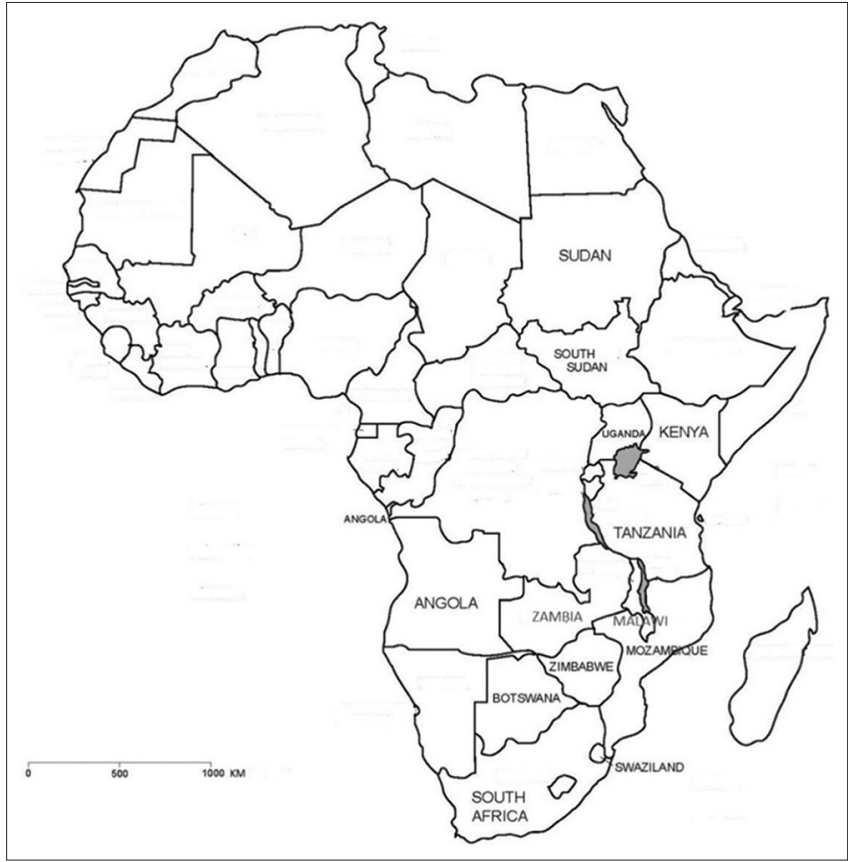

Fig. 1: Distribution of Drimia elata in tropical Africa

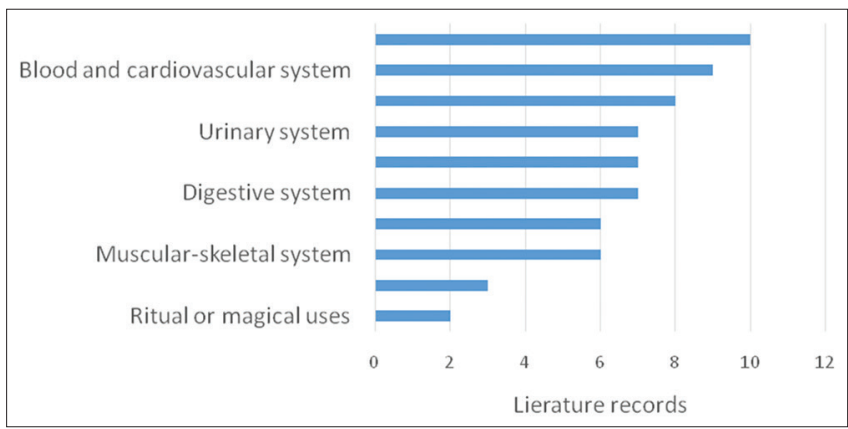

Fig. 2: Number of literature records per medicinal category of Drimia elata following the economic botany data collection standard [32]

aluminum, cadmium, manganese, and chromium being above the WHO recommended safety levels (Table 3). Quantities of mineral elements and phytochemical compounds isolated from D. elata are listed in Table 3.

\section{PHARMACOLOGICAL PROPERTIES OF D. ELATA}

Pharmacological studies on D. elata bulb and leaf extracts exhibited potent in vitro pharmacological activities including acetylcholinesterase enzyme inhibitory [2], antibacterial [2,43,50,70-80], antifungal [2,76], antimycobacterial [50], anticancer [81], anti-inflammatory [2,72,82,83], antioxidant [43,70], hemagglutinating [84], and cytotoxicity [43] activities.

\section{Acetylcholinesterase enzyme inhibitory activities}

Ndhlala et al. [2] investigated the acetylcholinesterase enzyme inhibitory activities of aqueous bulb extracts of D. elata using the enzyme isolated from electric eels with galanthamine as the positive control. The extract showed moderate AChE inhibitory activity of $50.0 \%$ with half maximal inhibitory concentration $\left(\mathrm{IC}_{50}\right.$ ) value of $487.4 \pm 8.0 \mu \mathrm{g} / \mathrm{mL}$ [2]. The ability of D. elata bulb extracts to inhibit acetylcholinesterase shows potential therapeutic potential of the species in the management of memory loss and neurodegenerative disorders.

\section{Antibacterial activities}

Luyt et al. [72] evaluated antibacterial activities of aqueous, ethyl acetate, and ethanol bulb and leaf extracts of D. elata against Bacillus 
Table 1: Medicinal uses of D. elata

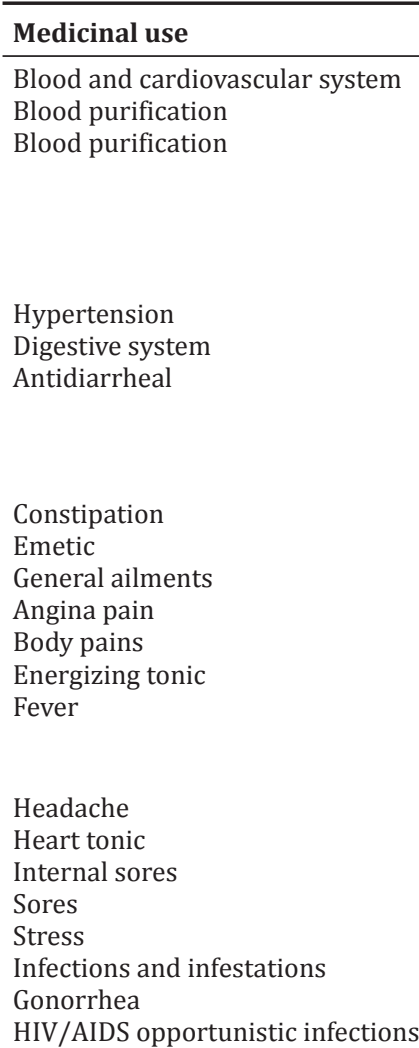

STIs

Tuberculosis

Muscular-skeletal system

Arthritis

Back pain

Edema

Inflammation

Muscle pain

Swelling

Pain

Pain

Reproductive system and sexual health Aphrodisiac

Erectile dysfunction

Impotence

Infertility

Respiratory system

Parts of the plant used

References

Bulbs or imbizae phuzwata concoction

Bulbs mixed with leaves, roots, and twigs of Kirkia wilmsii

Engl., Hypoxis hemerocallidea Fisch., C. A. Mey. and

Avé-Lall. (corms), Monsonia angustifolia E. Mey. ex A.

Rich. (leaves), and leaves of Sarcostem maviminale (L.) Br. and Vahlia capensis (L. f.) Thunb.

Bulbs

Bulbs mixed with leaves, roots, and twigs of

Kirkia wilmsii, Hypoxishem erocallidea (corms), Monsonia angustifolia (leaves), and leaves of Sarcostem maviminale, and Vahlia capensis

Imbizae phuzwata concoction

Bulbs

Bulbs

[48]

Imbizae phuzwata concoction

$[2,3$

$[2,3]$

Bulbs and leaves or bulbs mixed with roots of Artemisia afra

Jacq. ex Willd., Siphonochilus aethiopicus (Schweinf.) B. L.

Burtt and Erythrina caffra Thunb.

Bulbs

Bulbs

Bulbs

Bulbs and leaves

Imbizae phuzwata concoctions

Bulbs

Bulbs or bulbs mixed with twigs of Sarcostemm

aviminale (L.) R. Br. and roots of Elaeodendron

transvaalense (Burtt Davy) R. H. Archer,

Elephantor rhizaelephantina (Burch.) Skeels and

Zanthoxylumcapense (Thunb.) Harv. and bark of Sclero

caryabirrea (A. Rich.) Hochst.

Bulbs mixed with roots of Elaeodendron transvaalense,

Elephantor rhizaelephantina (roots), Sarcostemm

aviminale (twigs), Scleroc aryabirrea (bark), and Zantho

xylumcapense (root)

Bulbs or bulbs mixed with roots of Callilep islaureola DC,

Croton menyharthii Pax, Senna italica Mill. and bulb of

Siphonochilus aethiopicus (Schweinf.) B. L. Burtt or bulbs

mixed with the bark of Warburgi asalutaris (G. Bertol.)

Chiov. or bulbs mixed with leaves of Ricinus communis L. or

bulbs mixed with roots of Dicoma anomala Sond. and bulb

of Eucomis autumnalis (Mill.) Chitt.

Bulbs and imbizae phuzwata concoction

Bulbs

Bulbs

Bulbs and leaves

[41]

$[51]$

$[2,3]$

$[19,52,53]$

$[19,53,54]$

Bulbs

Bulbs

Bulbs and leaves or bulb mixed with leaves, roots, and twigs of Kirkia wilmsii, Hypoxis hemerocallidea (corm), Monsonia angustifolia (leaves), and leaves of Sarcostemma viminale and Vahlia capensis

Imbizae phuzwata concoction or bulbs mixed with

leaves, roots, and twigs of Kirkia wilmsii, Hypoxis hemerocallidea (corm), Monsonia angustifolia (leaves), and

leaves of Sarcostemma viminale and Vahlia capensis

Bulbs

Bulbs

Bulbs 
Table 1: (Continued)

\begin{tabular}{|c|c|c|}
\hline Medicinal use & Parts of the plant used & References \\
\hline Blocked nose & $\begin{array}{l}\text { Bulbs or bulbs mixed with roots of Artemisia afra, } \\
\text { Siphonochilus aethiopicus, and Erythrina caffra }\end{array}$ & {$[50]$} \\
\hline Chest pains & $\begin{array}{l}\text { Bulbs and leaves or bulbs mixed with leaves of Lippia } \\
\text { javanica (Burm. f.) Spreng. or bulbs mixed with roots of } \\
\text { Artemisia afra, Siphonochilus aethiopicus, and Erythrina } \\
\text { caffra or bulbs mixed with roots of Elaeodendron } \\
\text { transvaalense (Burtt Davy) R. H. Archer }\end{array}$ & {$[48-50]$} \\
\hline Cough & Bulbs mixed with leaves of Lippia javanica & {$[50]$} \\
\hline Expectorant & Bulbs & {$[45,47]$} \\
\hline Runny nose & Bulbs mixed with leaves of Lippia javanica & {$[50]$} \\
\hline Ritual or magical uses & & \\
\hline $\begin{array}{l}\text { Protect households from evil spirits and lightning, and } \\
\text { also to chase away, ward off or root out evil spirits } \\
\text { Urinary system }\end{array}$ & Intelezi herbal concoction & {$[4,45]$} \\
\hline Bladder complaints & Leaves & {$[1,15,58]$} \\
\hline Kidney problems & Imbizae phuzwata concoction & {$[2,3]$} \\
\hline Uterus problems & Bulbs and leaves & {$[1,15,58]$} \\
\hline
\end{tabular}

HIV: Human immunodeficiency virus, AIDS: Acquired immune deficiency syndrome, STIs: Sexually transmitted infections

Table 2: Bufadienolides isolated from D. elata bulb using NMR spectroscopy

\begin{tabular}{|c|c|c|}
\hline Bufadienolides & Extract & References \\
\hline Proscillaridin A & Chloroform: isopropanol & {$[72,73]$} \\
\hline Scilliroside & Chloroform or chloroform-n-butanol & [74] \\
\hline $12 \beta$-hydroxyscillirosidin & Chloroform or chloroform-n-butanol & {$[74]$} \\
\hline $12 \beta$-hydroxyscilliroside & Chloroform or chloroform-n-butanol & {$[74]$} \\
\hline Hellebrigenin-3-0- $\beta$-glucoside & Chloroform or chloroform-n-butanol & {$[74]$} \\
\hline $16 \beta$-hydroxyhellebrigenin & Chloroform or chloroform-n-butanol & {$[74]$} \\
\hline $16 \beta$-hydroxyhellebrigenin-3-0- $\beta$-glucoside & Chloroform or chloroform-n-butanol & {$[74]$} \\
\hline 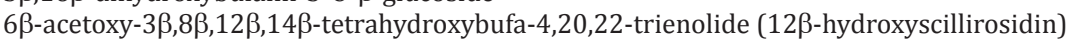 & Dichloromethane & [75] \\
\hline $14 \beta$-hydroxybufa- $4,20,22$-trienolide $3 \beta-0-\{\alpha-\mathrm{L}$-rhamnopyranosyl- $[(1 \rightarrow 4)$ - & Dichloromethane & [75] \\
\hline \multicolumn{3}{|l|}{$\beta$-D-glucopyranosyl]- $(1 \rightarrow 3)-\alpha$-L-rhamnopyranoside $\}$ (urginin) } \\
\hline 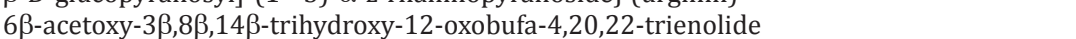 & Dichloromethane & [69] \\
\hline 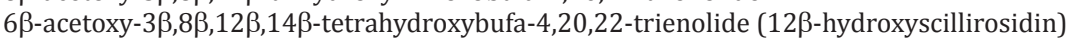 & Dichloromethane & [69] \\
\hline
\end{tabular}

NMR: Nuclear magnetic resonance

subtlis, Escherichia coli, Klebsiella pneumoniae, Micrococcus luteus, Pseudomonas aeruginosa, Staphylococcus aureus, and Staphylococcus epidermis using disk-diffusion assay with neomycin $(2 \mu \mathrm{g} / \mathrm{ml})$ as the positive control. Only ethyl acetate bulb extract was active against B. subtlis, K. pneumoniae, M. luteus, P. aeruginosa, and S. aureus with inhibition ratios ranging from 0.1 to 0.63 [72]. Ncube et al. [76] evaluated antibacterial activities of aqueous, dichloromethane, ethanol, and petroleum ether extracts of bulb and leaves of D. elata between spring, summer, autumn, and winter seasons against Bacillus subtilis, S. aureus, E. coli, and K. pneumoniae using the microdilution bioassay with neomycin $(\mu \mathrm{g} / \mathrm{ml})$ as the positive control. The extracts were active in all seasons except for winter when the leaves are not available showing minimum inhibitory concentration (MIC) values ranging from $0.8 \mathrm{mg} / \mathrm{ml}$ to $>12.5 \mathrm{mg} / \mathrm{ml}$ [76]. Ndhlala et al. [2] evaluated the antibacterial activities of aqueous, petroleum ether, dichloromethane, and ethanol bulb extracts of D. elata against Bacillus subtilis, E. coli, K. pneumoniae, and $S$. aureus using the microdilution bioassay with neomycin as the positive control. The extracts showed activities with MIC values ranging from 0.8 to $>12.5 \mathrm{mg} / \mathrm{mL}$ [2]. Baskaran et al. [77] evaluated the antibacterial activities of ethanol bulb, leaf, shoots, and plantlet extracts of in vitro and ex vitro regenerated D. elata in comparison to naturallygrown plants against $S$. aureus, Enterococcus faecalis, E. coli, and $P$. aeruginosa using the microdilution method with neomycin $(100 \mu \mathrm{l})$ as the positive control. All extracts exhibited activities with MIC values ranging from $0.2 \mathrm{mg} / \mathrm{ml}$ to $12.5 \mathrm{mg} / \mathrm{ml}$ [77]. Okem et al. [71] evaluated antibacterial activities of ethanol stem bulb extracts of $D$. elata against E. coli and S. aureus using microdilution assay with neomycin $(2 \mu \mathrm{g} / \mathrm{ml})$ as the positive control. The extracts exhibited activities with MIC values ranging from $6.3 \mathrm{mg} / \mathrm{mL}$ to $12.5 \mathrm{mg} / \mathrm{mL}$ [71]. Okem et al. [78] evaluated the effects of cadmium and aluminum accumulation on antibacterial activities of ethanol stem bulb extracts of D. elata against $E$. coli and S. aureus using microdilution assay with neomycin $(2 \mu \mathrm{g} / \mathrm{ml})$ as the positive control. The control extracts exhibited MIC values of $0.4 \mathrm{mg} / \mathrm{ml}$ and $0.8 \mathrm{mg} / \mathrm{ml}$ against $S$. aureus and E. coli, respectively, while antibacterial activities decreased in extracts exposed to increasing heavy metal stress with MIC values ranging from $0.8 \mathrm{mg} / \mathrm{ml}$ to $12.5 \mathrm{mg} / \mathrm{ml}$ [78]. Madisha [50] evaluated the antibacterial activities of ethanol, methanol, hydroethanol, and dichloromethane bulb extracts of D. elata against Bacillus cereus, E. faecalis, E. coli, Neisseria gonorrhoeae, Proteus vulgaris, P. aeruginosa, Shigella flexneri, S. aureus, Staphylococcus epidermidis, and Vibrio parahaemolyticus using agar well dilution method and streak plate disc diffusion assays. The extracts revealed varying degrees of activities with the zone of inhibition values ranging from $8.0 \mathrm{~mm}$ to $19.0 \mathrm{~mm}$ and MIC values ranging from $0.1 \mathrm{mg} / \mathrm{mL}$ to $12.5 \mathrm{mg} / \mathrm{mL}$ [50]. Madisha [50] also evaluated the antibacterial activities of ethanol and hydroethanol bulb extracts of D. elata mixed with roots of Elephantorrhiza elephantina and leaves of Aloe marlothii and Maurea angolensis against B. cereus, E. faecalis, E. coli, N. gonorrhea, P. vulgaris, P. aeruginosa, S. flexneri, $S$. aureus, S. epidermidis, and V. parahaemolyticus using agar well dilution method and streak plate disk diffusion assays. The extracts exhibited activities against tested pathogens with MIC values ranging from $0.4 \mathrm{mg} / \mathrm{mL}$ to $1.6 \mathrm{mg} / \mathrm{mL}$ [50]. Matotoka and Masoko [70] evaluated antibacterial activities of acetone and hexane extracts of $D$. elata bulb against $S$. aureus, E. faecalis, E. coli, and P. aeruginosa using the broth 
Table 3: Mineral and phytochemical composition of $D$. elata

\begin{tabular}{|c|c|c|c|}
\hline Mineral and phytochemical composition & Values & Plant parts & References \\
\hline Aluminum (mg/kg dry weight) & $559.8-1595.0$ & Bulbs & {$[70,71]$} \\
\hline Arsenic (mg/kg dry weight) & 1.8 & Bulbs & [71] \\
\hline Boron $(\mathrm{mg} / \mathrm{L})$ & 3.0 & Bulbs & [70] \\
\hline Cadmium (mg/kg dry weight) & $0.01-0.06$ & Bulbs & [71] \\
\hline Calcium $(\mathrm{mg} / \mathrm{L})$ & 19.0 & Bulbs & [70] \\
\hline Cobalt $(\mathrm{mg} / \mathrm{L})$ & 0.04 & Bulbs & [70] \\
\hline Copper (mg/kg dry weight) & $5.6-11.3$ & Bulbs & [71] \\
\hline Flavonoid (mg of quercetin equivalent/g extract) & $0.54-15.0$ & Bulbs and leaves & {$[43,71,76]$} \\
\hline Gallotannin ( $\mu$ g gallic acid equivalent/g dry weight) & $4.0-7.0$ & Bulbs and leaves & [76] \\
\hline Iron $(\mathrm{mg} / \mathrm{L})$ & 0.15 & Bulbs & [70] \\
\hline Iron (mg/kg dry weight) & $593.0-1634.0$ & Bulbs & [71] \\
\hline Lead (mg/kg dry weight) & $0.2-1.2$ & Bulbs & [71] \\
\hline Magnesium (mg/L) & 28.0 & Bulbs & [70] \\
\hline Manganese (mg/kg dry weight) & $60.7-145.8$ & Bulbs & {$[70,71]$} \\
\hline Mercury (mg/kg dry weight) & $0.04-0.8$ & Bulbs & [71] \\
\hline Phosphorus (mg/L) & 24.0 & Bulbs & [70] \\
\hline Potassium (mg/L) & 53.0 & Bulbs & [70] \\
\hline Silicon (mg/L) & 4.0 & Bulbs & [70] \\
\hline Sodium (mg/L) & 56.0 & Bulbs & [70] \\
\hline Sulfur $(\mathrm{mg} / \mathrm{L})$ & 7.0 & Bulbs & [70] \\
\hline Tannin (mg of gallic acid equivalent/g extract) & $4.5-9.6$ & Bulbs and leaves & {$[43,76]$} \\
\hline Tin (mg/kg dry weight) & $31.4-79.8$ & Bulbs & [71] \\
\hline Total phenolics (mg gallic acid equivalent/g dry weight) & $0.05-2.5$ & Bulbs and leaves & {$[43,71,76]$} \\
\hline Total saponins (mg diosgenin equivalent/g dry weight) & $5.0-17.0$ & Bulbs and leaves & [76] \\
\hline Total steroidal saponin (mg diosgenin equivalent/g dry weight) & $1.0-4.5$ & Bulbs and leaves & [76] \\
\hline Zinc $(\mathrm{mg} / \mathrm{L})$ & 0.1 & Bulbs & [70] \\
\hline Zinc (mg/kg dry weight) & $34.1-102.6$ & Bulbs & [71] \\
\hline
\end{tabular}

microdilution assay. The extracts exhibited activities against E. faecalis and $P$. aeruginosa with MIC values ranging from $0.6 \mathrm{mg} / \mathrm{mL}$ to 2.5 $\mathrm{mg} / \mathrm{mL}$ and total activities ranging from $3.3 \mathrm{~mL} / \mathrm{g}$ to $13.3 \mathrm{~mL} / \mathrm{g}$ [70]. Baskaran et al. [79] evaluated antibacterial activities of the aqueous bulb and root extracts of ex vitro grown $D$. elata derived from somatic embryogenesis against Bacillus subtilis, E. faecalis, M. luteus, S. aureus, E. coli, K. pneumonia, and P. aeruginosa using microtiter bioassay with neomycin $(\mu \mathrm{g} / \mathrm{ml})$ as a positive control. The extracts exhibited activities with MIC values ranging from $0.4 \mathrm{mg} / \mathrm{ml}$ to $6.3 \mathrm{mg} / \mathrm{ml}$ [79]. Kandari [80] evaluated antibacterial activities of aqueous, dichloromethane, and ethanol bulb extracts of D. elata subjected to vermicompost leachate at different concentrations against Bacillus subtilis, S. aureus, and $E$. coli using microdilution assay. The extracts exhibited activities with MIC values ranging from $0.4 \mathrm{mg} / \mathrm{ml}$ to $6.3 \mathrm{mg} / \mathrm{ml}$ [80]. Matotoka and Masoko [43] evaluated antibacterial activities of an herbal mixture of $D$. elata bulb together with leaves of $M$. angustifolia, $S$. viminale and Vahlia capensis, Kirkia wilmsii (leaves, roots, and twigs), and Hypoxis hemerocallidea (corm) against Bacillus subtilis, Citrobacter braakii, Enterobacter aerogenes, Enterobacter cloacae, E. faecalis, E. coli, K. pneumoniae, Leclercia adecarboxylata, Pantoea agglomerans, $P$. aeruginosa, and $S$. aureus using broth microdilution assay with ampicillin $(\mu \mathrm{g} / \mathrm{mL})$ as a positive control. The herbal mixture exhibited activities with MIC values ranging from $0.3 \mathrm{mg} / \mathrm{mL}$ to $>2.5 \mathrm{mg} / \mathrm{mL}$ [43]. The documented antibacterial activities exhibited by extracts of D. elata corroborate the traditional application of the species as herbal medicine against bacterial infections causing diarrhea [43], gonorrhea $[19,52,53]$, sexually transmitted infections [55], and sores [51].

\section{Antifungal activities}

Ncube et al. [76] evaluated antifungal activities of aqueous, dichloromethane, ethanol, and petroleum ether extracts of bulb and leaf extracts of D. elata between spring, summer, autumn, and winter seasons against Candida albicans using the microdilution bioassay with amphotericin B $(\mu \mathrm{g} / \mathrm{ml})$ as the positive control. The extracts were active in all seasons except for winter when the leaves are not available showing MIC and MFC values ranging from $0.4 \mathrm{mg} / \mathrm{ml}$ to
$>12.5 \mathrm{mg} / \mathrm{ml}$ [76]. Ndhlala et al. [2] investigated the antifungal activity of aqueous, petroleum ether, dichloromethane, and ethanol bulb extracts of D. elata against $C$. albicans using the microdilution assay with amphotericin B as the positive control. The extracts exhibited activities with MIC and MFC values ranging from 3.1 to $6.3 \mathrm{mg} / \mathrm{mL}$ and $6.3 \mathrm{mg} / \mathrm{mL}$ to $12.5 \mathrm{mg} / \mathrm{mL}$ [2].

\section{Antimycobacterial activities}

Madisha [50] evaluated the antimycobaceterial activities of ethanol, methanol, hydroethanol, and dichloromethane bulb extracts of D. elata against Mycobacterium tuberculosis, Mycobacterium smegmatis, Mycobacterium peregrinum, and Mycobacterium haemophilus using agar well dilution method and streak plate disc diffusion assays. The extracts revealed varying degrees of activities with the zone of inhibition values ranging from $9.0 \mathrm{~mm}$ to $21.0 \mathrm{~mm}$ and MIC values ranging from $0.1 \mathrm{mg} / \mathrm{mL}$ to $12.5 \mathrm{mg} / \mathrm{mL}$ [50]. Madisha [50] also evaluated the antimycobacterial activities of ethanol and hydroethanol bulb extracts of D. elata mixed with roots of Elephantor rhizaelephantina and leaves of $A$. marlothii and M. angolensis against $M$. tuberculosis, M. smegmatis, M. peregrinum, and M. haemophilus using agar well dilution method and streak plate disc diffusion assays. The extracts exhibited activities against tested pathogens with MIC values ranging from $0.1 \mathrm{mg} / \mathrm{mL}$ to $1.6 \mathrm{mg} / \mathrm{mL}$ [50]. These findings show the potential of $D$. elata in the treatment and management of respiratory problems such as blocked nose [48], chest pains [46-48], colds [43,44,47], cough [48], and runny nose [50].

\section{Anticancer activities}

Fouche et al. [81] evaluated in vitro anticancer activities of dichloromethane:methane $(1: 1)$ of the whole plant of $D$. elata against a panel of three human cell lines (breast MCF7, renal TK10, and melanoma UACC62). The extract exhibited total growth inhibition values ranging from $6.3 \mu \mathrm{g} / \mathrm{ml}$ to $29.6 \mu \mathrm{g} / \mathrm{ml}$. The extracts were screened against 60 human cancer cell lines organized into sub-panels representing leukemia, melanoma, cancer of the lung, colon, kidney, ovary, central nervous system, breast, and prostate. The extract exhibited total 
growth inhibition values of $1.1 \mu \mathrm{g} / \mathrm{ml}$ against ovarian (OVCAR-3), $1.4 \mu \mathrm{g} / \mathrm{ml}$ against central nervous system cancer, CNSC SF-539 and $1.4 \mu \mathrm{g} / \mathrm{ml}$ against non-small cell lung cancer, NSCLC A549/ATCC [81]. The documented anticancer activities may be attributed to bufadienolides as these compounds are known to have anticancer activities [62-68].

\section{Anti-inflammatory activities}

Luyt et al. [72] evaluated anti-inflammatory activities of aqueous, ethyl acetate, and ethanol bulb and leaf extracts of D. elata using the cyclooxygenase assay with indomethacin as the positive control. The bulb extracts inhibited cyclooxygenase with inhibition ranging from $69.0 \%$ to $98.0 \%$ which was comparable to $94 \%$ exhibited by indomethacin, the positive control [72]. Stafford et al. [82] evaluated anti-inflammatory activities of aqueous, ethanol, and hexane bulb extracts of fresh and stored material of $D$. elata by assessing their ability to inhibit cyclooxygenase (COX)- 1 enzymes. The ethanol extract showed high inhibition level of $96.0 \%$ which decreased to $76.0 \%$ of the COX-1 enzyme after 90 days of storage while aqueous extract showed $61.0 \%$ inhibition which decreased to $0 \%$ of the COX- 1 enzyme after 90 days of storage [82]. Ndhlala et al. [2] investigated the anti-inflammatory effects of aqueous, dichloromethane, ethanol, and petroleum ether bulb extracts of D. elata using COX-1 and COX-2 inhibitory bioassays. The aqueous and ethanol extracts showed percentage inhibition of over $80.0 \%$ and $48.0 \%$, respectively, for COX-1 while only the aqueous extract showed moderate inhibition of over $55.0 \%$ for COX-2 enzyme [2]. Ncube et al. [83] evaluated the anti-inflammatory activities of aqueous, dichloromethane, ethanol, and petroleum ether bulb and leaf extracts of D. elata collected in spring, summer, autumn, and winter seasons by assessing their ability to inhibit COX-1 and COX-2 enzymes. The dichloromethane and petroleum ether bulb and leaf extracts in all seasons except for winter when the leaves are not available showed moderate to high inhibition levels ranging from $58.0 \%$ to $94.1 \%$ of the COX-1 enzyme. A similar trend was observed for COX-2 enzyme with inhibition levels ranging from $52.8 \%$ to $91.2 \%$ [83]. These findings support the traditional use of $D$. elata as herbal medicine for back pain [39], body pains [2,3],inflammation [51], muscle pain [41], pain [43,46,51], and swelling [39].

\section{Antioxidant activities}

Matotoka and Masoko [70] evaluated antioxidant activities of acetone and hexane extracts of D. elata bulb using 2,2-diphenyl-1-picrylhydrazyl (DPPH) free radical scavenging assay. The hexane extracts exhibited antioxidant activities [70]. Matotoka and Masoko [43] evaluated antioxidant activities of an herbal mixture of $D$. elata bulb together with leaves of M. angustifolia, S. viminale and Vahlia capensis, Kirkia wilmsii (leaves, roots, and twigs), and Hypoxis hemerocallidea (corm) using the DPPH free radical scavenging assay and ferric reducing power with L-ascorbic acid as the positive control. The free radical scavenging activity showed that the herbal concoction exhibited moderate antioxidant activities. The ferric reducing power measuring the reduction of $\mathrm{Fe} 3+$ to $\mathrm{Fe} 2+$ revealed that the herbal concoction exhibited good reducing activity compared to L-ascorbic acid, the positive control [43]. The documented antioxidant activities of the bulb extracts of $D$. elata are probably due to flavonoids, gallotannins, phenolics, saponins, and tannins which have been isolated from the species $[43,71,76]$.

\section{Hemagglutinating activities}

Gaidamashvili and Van Staden [84] evaluated hemagglutinating activities of aqueous bulb extracts of $D$. elata toward fresh and glutaraldehyde-treated rabbit erythrocytes using the hemagglutination and hapten inhibition assays. The extracts yielded hemagglutinating activity which was detected in the crude protein extracts at the minimal concentrations of $19.9 \mathrm{mg} / \mathrm{ml}$. The was inhibited by $200 \mathrm{mM}$ lactose along with major inhibition by $\mathrm{D}(+)$ trehalose, $>\mathrm{DL}$ arabinose, and $\mathrm{D}$ fructose [84]. The documented information on hemagglutinating activities and the identification of proteins from $D$. elata may be useful for future characterization of the species extracts in developing pharmaceutical products.

\section{Cytotoxicity activities}

Matotoka and Masoko [43] evaluated cytotoxicity activities of an herbal mixture of $D$. elata bulb together with leaves of M. angustifolia, S. viminale and Vahlia capensis, Kirkia wilmsii (leaves, roots, and twigs), and Hypoxis hemerocallidea (corm) using the 3-(4,5-dimethylthiazol2-yl)-2,5-diphenyl tetrazolium bromide calorimetric assay with actinomycin $\mathrm{D}$ as the negative control. The cytotoxic concentration $\left(\mathrm{CC}_{50}\right)$ values of all the concoctions were above the highest concentration used $(1000 \mu \mathrm{g} / \mathrm{mL})$ and Actinomycin D; the negative control exhibited $\mathrm{CC}_{50}$ value of $0.6 \mu \mathrm{g} / \mathrm{mL}$ [43]. The documented cytotoxicity activities exhibited by $D$. elata extracts may be attributed to bufadienolides as these compounds are known to have cytotoxicity activities [64,65].

\section{CONCLUSION}

Based on information about D. elata that has been documented in this review, there appear to be research gaps on ethnopharmacological evaluation and clinical research on the species. No in vivo evaluations nor an assessment of target-organ toxicity have been carried out using the extracts from the species. Since D. elata is widely used in combination with other plant species in various herbal concoctions, there is a need for extensive research to evaluate synergistic effects of the different extracts and also to evaluate their ability to enhance the efficiency of the additive mixtures. Future research should also focus on aerial parts of the species to ensure full utilization of the possible medicinal potential of the species. Literature studies show that the major phytochemical compounds isolated from D. elata so far are mainly bufadienolides but very little attempt has been made to correlate the activities of these compounds with the ethnomedicinal uses of the species. Therefore, detailed phytochemical studies of D. elata and its pharmacological properties, especially the mechanism of action of its bioactive constituents to illustrate the correlation between its ethnomedicinal uses and pharmacological activities should be the focus of future research studies. Extensive in vivo experiments are required to validate the existing pharmacological activities. Since D. elata contain potentially toxic compounds, future studies should research on how potential toxic components of the species can be managed.

\section{AUTHOR'S CONTRIBUTIONS}

The author declares that this work was done by the author named in this article.

\section{CONFLICTS OF INTEREST}

The author declares that there are no conflicts of interest regarding the publication of this paper.

\section{ACKNOWLEDGMENTS}

The author would like to express his gratitude to the National Research Foundation (NRF), South Africa and Govan Mbeki Research and Development Centre (GMRDC), University of Fort Hare for financial support to conduct this study.

\section{REFERENCES}

1. Van Wyk BE, Oudtshoorn BV, Gericke N. Medicinal Plants of South Africa. Pretoria: Briza Publications; 2013.

2. NdhlalaAR, Finnie JF, Van Staden J. Plant composition, pharmacological properties and mutagenic evaluation of a commercial zulu herbal mixture: Imbiza ephuzwato. J Ethnopharmacol 2011;133:663-74.

3. Maroyi A. From traditional usage to pharmacological evidence: Systematic review of Gunnera perpensa L. Evidence Based Complement Altern Med 2016;2016:14.

4. Ndhlala AR, Van Staden J. Smokescreens and mirrors in safety and quality of herbal medicines: A case of commercialized herbal preparations. S Afr J Bot 2012;82:4-10.

5. Williams VL, Balkwill K, Witkowski ET. Unraveling the commercial market for medicinal plants and plant products on the Witwatersrand, South Africa. Econ Bot 2000;54:310-37.

6. Dold AP, Cocks ML. The trade in medicinal plants in the Eastern Cape Province, South Africa. S Afr J Sci 2002;98:589-97. 
7. Loundou PM. Medicinal Plant Trade and Opportunities for Sustainable Management in the Cape Peninsula, South Africa. MSc Dissertation, Cape Town: University of Stellenbosch; 2008.

8. Cunningham AB. African Medicinal Plants: Setting Priorities at the Interface between Conservation and Primary Health Care. Paris: People and Plants Working Paper 1, UNESCO; 1993.

9. Williams VL. The Witwatersrand muti trade. Veld Flora 1996;82:12-4.

10. Williams VL, Balkwill K, Witkowski ET. A lexicon of plants traded in the Witwatersrand umuthi shops, South Africa. Bothalia 2001;31:71-98.

11. Ndawonde BG, Dlamini ET, Imenda SN. Indigenous knowledge, women and issues of sustainable development. WIT Trans Ecol Environ 2011; $167: 45-54$

12. Moeng TE. An Investigation into the Trade of Medicinal Plants by Muthi Shops and Street Vendors in the Limpopo Province, South Africa. MSc Dissertation, Sovenga: University of Limpopo; 2010.

13. Petersen LM, Moll EJ, Collins R, Hockings MT. Development of compendium of local, wild-harvested species used in the informal economy trade, Cape Town, South Africa. Ecol Soc 2012;17:26.

14. Philander LE, Makunga NP, Esler KJ. The informal trade of medicinal plants by Rastafari bush doctors in the Western Cape of South Africa. Econ Bot 2014;68:303-15.

15. Ndawonde BG, Zobolo AM, Dlamini ET, Siebert SJ. A survey of plants sold by traders at Zululand muthi markets, with a view to selecting popular plant species for propagation in communal gardens. Afr J Range Forage Sci 2007;24:103-7.

16. Marshall NT. Searching for a Cure: Conservation of Medicinal Wildlife Resources in East and Southern Africa. Cambridge: TRAFFIC International; 1998.

17. Wiersum KF, Dold AP, Husselman M, Cocks ML. Cultivation of medicinal plants as a tool for biodiversity conservation and poverty alleviation in the Amatola region, South Africa. In: Bogers RJ, Craker LE, Lange D, editors. Medicinal and Aromatic Plants: Agricultural, Commercial, Ecological, Legal, Pharmacological and Social Aspects. Wageningen: Springer; 2006. p. 43-57.

18. Maroyi A, Mosina GK. Medicinal plants and traditional practices in peri-urban domestic gardens of the Limpopo province, South Africa. Indian J Tradit Knowl 2014; 13:665-72.

19. Semenya SS, Potgieter MJ. Medicinal plants cultivated in bapedi traditional healers homegardens, Limpopo province, South Africa. Afr J Tradit Complement Altern Med 2014;11:126-32.

20. Mosina GK, Maroyi A, Potgieter MJ. Useful plants grown and maintained in domestic gardens of the Capricorn District, Limpopo province, South Africa. Stud Ethno Med 2015;9:43-58

21. Azizi N, Amirouche R, Amirouche N. Cytotaxonomic diversity of some medicinal species of hyacinthaceae from Algeria. Pharmacogn Commun 2016;6:34-8

22. Angiosperm Phylogeny Group (APG III). An update of the angiosperm phylogeny group. Classification for the orders and families of flowering plants: APG III. Bot J Linn Soc 2009;161:105-21.

23. Chase MW, Reveal JL, Fay MF. A subfamilial classification for the expanded asparagalean families, amaryllidaceae, asparagaceae and xanthorrhoeaceae. Bot J Linn Soc 2009;161:132-6.

24. Manning JC, Goldblatt P, Fay MF. A revised generic synopsis of hyacinthaceae in sub-Saharan Africa, based on molecular evidence, including new combinations and the new tribe pseudoprospereae. Edinburgh J Bot 2004;60:533-68

25. Manning JC, Deacon J, Goldblatt P. A review of the schizobasis group of Drimia Jacq. (Hyacinthaceae: Urgineoideae), and the new species D. sigmoidea from Western Cape, South Africa. S Afr J Bot 2014;94: 263-9.

26. Jessop JP. Studies in the bulbous liliaceae in South Africa: 7. The taxonomy of Drimia and certain allied genera. J S Afr Bot 1977;43: 265-319.

27. Stedje B. A revision of the genus Drimia (Hyacinthaceae) in East Africa. Nordic J Bot 1987;7:655-66.

28. Stedje B. Hyacinthaceae. In: Polhill RM, editor. Flora of Tropical East Africa. Rotterdam: A. Balkema; 1996. p. 1-32.

29. Germishuizen G, Meyer NL. Plants of Southern Africa: An Annotated Checklist. Pretoria: Strelitzia 14, National Botanical Institute; 2003.

30. Figueiredo E, Smith GF. Plants of Angola. Pretoria: Strelitzia 22, South African National Biodiversity Institute; 2008.

31. Darbyshire I, Kordofani M, Farag I, Candiga R, Pickering H. The Plants of Sudan and South Sudan. London: Kew Publishing, Royal Botanic Gardens, Kew; 2015

32. Cook FE. Economic Botany Data Collection Standard. London: Prepared for the International Working Group on Taxonomic Databases for Plant Sciences (TDWG), Kew Royal Botanic Gardens, Kew; 1995.
33. Macía MJ, Armesilla PJ, Cámara-Leret R, Paniagua-Zambrana N, Villalba S, Balslev H, et al. Palm uses in Northwestern South America: A quantitative review. Bot Rev 2011;77:462-570.

34. Gruca M, Cámara-Leret R, Macía MJ, Balslev H. New categories for traditional medicine in the economic botany data collection standard. J Ethnopharmacol 2014;155:1388-92.

35. World Health Organization (WHO). Atlas of African Health Statistics 2014. Geneva: Health Situation Analysis of the African Region, World Health Organization; 2014

36. Gurib-Fakim A. Medicinal plants: Traditions of yesterday and drugs of tomorrow. Mol Aspects Med 2006;27:1-93

37. Maroyi A. Euclea crispa: Review of its botany, ethnomedicinal uses and pharmacological properties. Asian J Pharm Clin Res 2018;11:5-9.

38. Maroyi A. Dicoma anomala Sond: A review of its botany, ethnomedicine, phytochemistry and pharmacology. Asian J Pharm Clin Res 2018;11:70-7

39. Philander LA. An ethnobotany of Western Cape Rasta bush medicine. J Ethnopharmacol 2011;138:578-94

40. Semenya SS, Potgieter MJ, Tshisikhawe MP. Use, conservation and present availability status of ethnomedicinal plants of Matebele-Village in the Limpopo Province, South Africa. Afr J Biotechnol 2013;12:2392-405.

41. Maema LP, Mahlo SM, Potgieter MJ. Ethnomedicinal uses of indigenous plant species in Mogalakwena municipality of Waterberg district, Limpopo province, South Africa. Int J Tradit Complement Med 2016;1: $28-44$.

42. Masafu MM, Mbajiorgu CA, Nemadodzi LE, Kabine ES. A study of natural habitats and uses of medicinal plants in Thulamela and JS Moroka municipalities, South Africa. Indian J Tradit Knowl 2016;15: 363-9.

43. Matotoka MM, Masoko P. Phytochemical screening and pharmacological evaluation of herbal concoctions sold at Ga Maja Limpopo province. S Afr J Bot 2018;117:1-10.

44. Semenya SS, Wadesango N. Ethnobotanical survey of plants used by bapedi traditional healers to treat hypertension in the Polokwane munucipality, Limpopo province, South Africa. Indilinga Afr J Indig Knowl Syst 2018;17:109-29.

45. Hutchings A, Scott AH, Lewis G, Cunningham AB. Zulu Medicinal Plants: An Inventory. Pietermaritzburg: University of Natal Press; 1996

46. Long C. Swaziland's flora: siSwati Names and Uses. Swaziland National Trust Commission, Mbambane; 2005. Available from: http:// www.sntc.org.sz/index.asp.

47. Van Wyk BE, Gericke N. Peoples Plants: A Guide to Useful Plants of Southern Africa. Pretoria: Briza Publications; 2007.

48. Semenya SS, Maroyi A. Ethnobotanical survey of plants used by bapedi traditional healers to treat tuberculosis and its opportunistic infections in the Limpopo Province, South Africa. S Afr J Bot 2018. Doi: 10.1016/j. sajb.2018.10.010.

49. Hutchings A. Plants Used for Some Stress-related Ailments in Traditional Zulu, Xhosa and Sotho Medicine. MSc Dissertation. Pietermaritzburg: University of Natal; 1992.

50. Madisha JK. Antimycobacterial Activities of Selected Plants Used in the Management of Tuberculosis in Sekhukhune (Limpopo Province), South Africa. MSc Dissertation. Bloemfontein: University of the Free State; 2017.

51. Hulley IM, Van Wyk BE. Quantitative medicinal ethnobotany of Kannaland (Western Little Karoo, South Africa): non-homogeneity amongst villages. S Afr J Bot 2018. Doi: 10.1016/j.sajb.2018.03.014.

52. Erasmus LJ, Potgieter MJ, Semenya SS, Lennox SJ. Phytomedicine versus gonorrhoea: The bapedi experience. Afr J Tradit Complement Altern Med 2012;9:591-8.

53. Semenya SS, Potgieter MJ, Erasmus LJ. Indigenous plant species used by bapedi healers to treat sexually transmitted infections: Their distribution, harvesting, conservation and threats. S Afr J Bot 2013;87: 66-75.

54. Semenya SS, Potgieter MJ, Erasmus LJ. Ethnobotanical survey of medicinal plants used by bapedi traditional healers to manage HIV/ AIDS in the Limpopo province, South Africa. J Med Plants Res 2013; 7:434-41.

55. Semenya SS, Potgieter MJ, Erasmus LJC, Bapedi phytomedicine and their use in the treatment of sexually transmitted infections in Limpopo province, South Africa. Afr J Pharm Pharmacol 2013;7:250-62.

56. Semenya SS, Potgieter MJ. Ethnobotanical survey of medicinal plants used by bapedi traditional healers to treat erectile dysfunction in the Limpopo Province, South Africa. J Med Plants Res 2013;7:349-57.

57. Semenya SS, MaroyiA, PotgieterMJ, Erasmus LJ. Herbal medicines used by bapedi traditional healers to treat reproductive ailments in the Limpopo 
Province, South Africa. Afr J Tradit Complement Altern Med 2013; 10:331-9.

58. Pujol J. Natur Africa: The Herbalist Handbook, African Flora, Medicinal Plants. Durban: Jean Pujol Natural Healers Foundation; 1990.

59. Kellerman TS, Coetzer JA, Naudé TW. Plant Poisonings and Mycotoxicoses of Livestock in Southern Africa. Cape Town: Oxford University Press; 1988

60. Kellerman TS, Naudé TW, Fourie N. The distribution, diagnosis and estimated economic impact of plant poisonings and mycotoxicoses in South Africa. Onderstepoort J Vet Res 1996;63:65-90.

61. Van Wyk BE, Van Heerden F, Van Oudtshoorn B. Poisonous Plants of South Africa. Pretoria: Briza Publications; 2005.

62. Kupchan SM, Hemingway RJ, Hemingway JC. The isolation and characterization of hellebrigenin 3-acetate and hellebrigenin 3,5-diacetate, bufadienolide tumor inhibitors from Bersama abyssinica. Tetrahedron Lett 1968;2:149-52

63. Kupchan SM, Ognyanov I, Moniot JL. Tumor inhibitors. 64. Isolation and structural elucidation of novel bufadienolides, the cytotoxic principles of Bersama abyssinica. Bioorg Chem 1971;1:13-31.

64. Yamagishi T, Yan XZ, Wu RY, McPhail DR, McPhail AT, Lee KH, et al. Structure and stereochemistry of bryophyllin-A, a novel potent cytotoxic bufadienolide orthoacetate from Bryophyllum pinnatum. Chem Pharm Bull (Tokyo) 1988;36:1615-7.

65. Yamagishi T, Haruna M, Yan XZ, Chang JJ, Lee KH. Antitumor agents, 110. bryophyllin B, a novel potent cytotoxic bufadienolide from Bryophyllum pinnatum. J Nat Prod 1989;52:1071-9.

66. Supratman U, Fujita T, Akiyama K, Hayashi H, Murakami A, Sakai H, et al. Anti-tumorpromoting activity of bufadienolides from Kalanchoe pinnata and $K$. daigremontiana Xbutiflora. Biosci Biotechnol Biochem 2001;65:947-9.

67. Moodley N, Crouch NR, Mulholland DA. Bufadienolides from Drimia macrocentra and Urginea riparia (Hyacinthaceae: Urgineoideae). Phytochemistry 2007;68:2415-9.

68. Dai Y, Harinantenaina L, Brodie PJ, Goetz M, Shen YY, Dyke KT, et al. Antiproliferativehomoiso flavonoids and bufatrienolides from Urginea depressa. J Nat Prod 2013;76:865-72.

69. Koorbanally NA, Koorbanally C, Harilal A, Mulholland DA, Crouch NR. Bufadienolides from Drimia robusta and Urginea epigea (Hyacinthaceae). Phytochemistry 2004;65:3069-73.

70. Matotoka MM, Masoko P. Evaluation of herbal concoctions sold at Ga Maja (Limpopo Province) in South Africa and in vitro pharmacological evaluation of plants used to manufacture the concoctions. J Evidence
Based Complement Altern Med 2017;22:805-15.

71. Okem A, Southway C, Stirk WA, Street RA, Finnie JF, Van Staden J. Heavy metal contamination in South African medicinal plants: A cause for concern. S Afr J Bot 2014;93:125-30.

72. Luyt RP, Jäger AK, Van Staden J. The rational usage of Drimia robusta Bak. In traditional medicine. S Afr J Bot 1999;65:291-4.

73. Luyt RP, Jäger AK, Van Staden J. Bufadienolides in in vitro derived Drimia robusta plants. S Afr J Bot 1999;65:443-5.

74. Krenn L, Stapf V, Kopp B. Bufadienolides from Drimia robusta BAK. Sci Pharm 2000;68:421-7.

75. Pohl T, Koorbanally C, Crouch NR, Mulholland DA. Bufadienolides from Drimia robusta and Urginea altissima (Hyacinthaceae). Phytochemistry 2001;58:557-61.

76. Ncube B, Finnie JF, Van Staden J. Seasonal variation in antimicrobial and phytochemical properties of frequently used medicinal bulbous plants from South Africa. S Afr J Bot 2011;77:387-96.

77. Baskaran P, Singh S, Van Staden J. In vitro propagation, proscillaridin A production and antibacterial activity in Drimia robusta. Plant Cell Tissue Organ Cult 2013;114:259-67.

78. Okem A, Southway C, Stirk WA, Street RA, Finnie JF, Van Staden J. Effect of cadmium and aluminum on growth, metabolite content and biological activity in Drimia elata (Jacq.) Hyacinthaceae. S Afr J Bot 2015;98:142-7.

79. Baskaran P, Kumari A, Van Staden J. Analysis of the effect of plant growth regulators and organic elicitors on antibacterial activity of Eucomis autumnalis and Drimia robusta ex vitro-grown biomass. Plant Growth Regul 2018;85:143-51.

80. Kandari LS. Effect of vermicompostleachate on biomass and antibacterial properties of five bulbous medicinal plants: A case study from Kwa Zulu Natal, South Africa. Iran J Sci Technol Trans A Sci 2018;42:1049-56.

81. Fouche G, Gragg GM, Pillay P, Kolesnikova N, Maharaj VJ, Senabe J. In vitro anticancer screening of South African plants. J Ethnopharmacol 2008;119:455-61.

82. Stafford GI, Ja"ger AK, Van Staden J. Effect of storage on the chemical composition and biological activity of several popular South African medicinal plants. J Ethnopharmacol 2005;97:107-15

83. Ncube B, Finnie JF, Van Staden J. Seasonal variation in the cyclooxygenase inhibitory activities of four South African medicinal bulbs. S Afr J Bot 2012;78:246-51.

84. Gaidamashvili M, Van Staden J. Lectin-like proteins from South African plants used in traditional medicine. S Afr J Bot 2002;68:36-40. 